\title{
An insight into the prophylactic and therapeutic activities of golden apple (Cydonia oblonga Mill.) for the future cancer care and prevention: A review
}

\author{
Elhan Khan and Iffat Zareen Ahmad* \\ Natural Products Laboratory, Department of Bioengineering, Integral University, Dasauli, Kursi Road, Lucknow-226026, Uttar Pradesh,
} India

\section{Article Info}

\section{Article history}

Received 1 August 2021

Revised 17 September 2021

Accepted 18 September 2021

Published Online 30 December 2021

\section{Keywords}

Quince

Cydonia oblonga Mill.

Bioactive compounds

Cancer

Antioxidant

Anticancer

\begin{abstract}
Cancer has become a significant concern to human health as it has become a second leading cause of mortality and morbidity worldwide and for its prevention, no "silver bullet" yet exists. However, medicinal plants have become an attractive source in the development of agents for cancer treatment and its related complications. Cydonia oblonga Mill., also known as quince, belongs to the Rosaceae family, sole member of genus Cydonia. Quince, is one of the reported plants, conventionally flourished for its medicinal, nutritional and ornamental values. Quince plant is reported for its antioxidant, antiseptic, antiinflammatory, hepatoprotective, antiproliferative and anticancer activities mainly, owing to the presence of flavonoids and phenols as an active constituent. The major polyphenol compounds reported to be present in quince products are caffeoylquinic acid along with quercetin and kaempferol glycosides. This review aims to collect the data on $C$. oblonga and its bioactive metabolites that can be used in future cancer care and prevention. The current article directed toward exploring the beneficial therapeutical potential of quince plant and its derived bioactive compounds. Nearly one hundred of reviews are cited in this review, reported the antioxidant, anticancerous, hepatoprotective and other anticarcinogenic activity, making it a novel source cancer prevention and care. Therefore, this review intends to report the mechanism known by which Cydonia impede cancer progression and its use for the establishment of a new, safer and inexpensive drugs.
\end{abstract}

\section{Introduction}

Cancer is an unpredictable and one of the most complex noncommunicable diseases of uncontrolled cell proliferation with a hallmark to invade and metastasize to further parts of the body. It has become a significant concern for human health as it is the second leading cause of mortality and morbidity worldwide. From the 2018 GLOBOCON report (Siegel et al., 2020), 18.1 million new cases and mortality about 9.6 million in 2018 were reported with the five-year prevalence 43.8 million depicting the rise in the global cancer burden. According to the report, the developing countries like Europe and USA accounts for $23.4 \%$ and $21.0 \%$ of the new cancer cases incidence, respectively, while $20.3 \%$ of the deaths due to cancer in Europe and $14.4 \%$ of mortality rate in USA. Whereas, developing countries like Asia and Africa have greater mortality (57.3\% and 7.3\%, respectively) due to number of cancer cases is higher than the proportions of incident ( $48.4 \%$ and $5.8 \%$, respectively) cases of cancer because of the poor prognosis, late diagnosis and higher mortality of certain types of cancer that are associated with these regions at a higher frequency. In worldwide, lung carcinoma is responsible for the most considerable number of deaths, i.e., 1.8 million cancer deaths, followed

\section{Corresponding author: Dr. Iffat Zareen Ahmad}

Professor, Natural Products Laboratory, Department of Bioengineering, Integral University, Dasauli, Kursi Road, Lucknow-226026, Uttar Pradesh, India

E-mail: iffat@iul.ac.in

Tel.: +91-9919273517

Copyright $\odot 2021$ Ukaaz Publications. All rights reserved.

Email: ukaaz@yahoo.com; Website: www.ukaazpublications.com by colorectal cancer $(9.2 \%)$, cancer of stomach $(8.2 \%)$, and hepatocarcinoma.

According to the 2020 data in India by ICMR, 1,392,179 number of cancer patients were projected, with the cancer of breast, lung, mouth, cervix, uteri and tongue are the most common 5 leading sites. The majority of cancer patients were diagnosed with locally advanced breast cancer $(57.0 \%)$, cervix uteri cancer $(60.0 \%)$, head and neck cancer $(66.6 \%)$ and stomach cancer $(50.8 \%)$, while remote metastasis was predominant in lung cancer among men $(44.0 \%)$ and women (47.6\%). From the Breast Cancer India statistics, over the last 25 years, breast cancer incidence rate has doubled, which accounts for 25-32\% of all cancers affecting Indian women (Mathur et al., 2020). As regards the cancer burden, East Asian countries (like Japan, Korea and China) are facing a strong burden of cancers of the upper digestive tract. The 2018 GLOBOCON report estimated about 4,285,033 new cancer cases and about 2,865,174 deaths occurred in China due to cancer, accounting with $1,791,805$ number of deaths in males and $1,073,369$ mortalities occurring in females in 2018 because of cancer. The report shows higher incidence and mortality rates in males than in females. The crude and age-standardized mortality rates (ASMR) of breast cancer was highest in both the sexes integrated, followed by then the cancer of lung, colorectal cancer and stomach cancer (Sun et al., 2020).

Medicinal plants have become an attractive source in the development of agents for cancer treatment and its related complications. Several reviews aiming at the discovered phytochemicals for cancer care and management have been reported. C. oblonga is one of the reported plants for its wide range of phytochemicals and 
therapeutical activities in the traditional medicine system (Karimi et $a l ., 2017)$. This review is mainly focused on its phytochemicals that may or may not become the future agents for various types of cancer prevention and treatment.

\subsection{Botanical description and morphology}

C. oblonga is also known as quince, belongs to the Rosaceae family, is a sole member of genus Cydonia, is conventionally flourishing for its prophylactic, nutritional and ornamental values. The fruit of this plant is famously known as "The Golden Apple." The tree has been cultivated in the region of northwestern Coast of Crete Greece called Kydonia since the ancient times where its fruits were offered as a symbol of fertility in weddings and hence, the name Cydonia as it is derived from this region (Postman, 2009). In India, quince is harvested in high quantity in regions of Anantnag, Budgam, Kupwara and Pulwama of Kashmir (Srivastava et al., 2005).

\subsubsection{Taxonomy}

Domain: Eukaryotic; Kingdom: Plantae; Phylum: Tracheophyta; Class: Magnoliopsida; Order: Rosales; Family: Rosaceae; Genus: Cydonia Mill.; Species: Cydonia oblonga Mill.

Synonyms: Cydonia oblonga Mill., C. vulgris Pers., C. maliformis Mill., C. lusitanica Mill., Pyrus cydonia L., Cydonia cydonia var. lusitanica (Mill.) Pers., C. vulgaris var. lusitanica (Mill.) DC, $C$. oblonga f. lusitanica (Mill.) Rehder.

\subsubsection{Vernacular name in India}

It is commonly known as Safarjal, Bihi and Bihidana in Unani and Amritphala in Sanskrit. However, in different parts of India, it is called by names like Simodalibe in Kerala, Bamsutu in Kashmir and in Tamil it is known by the name of Simadanimma and Shimaimathala.
English: Quince; China: Wen po; Arabic: Sefarjal; Iran: Heyva; France: Cognassier, Coing, Coigner; Germany: Quitte, Quittenbaum; Sweden: Kvitten; Greece: Strythion; Italy: Cotogno, Melo Cotogno, Pero Cotogno; Persian: Beh; Russia: Ajva; Spain: Membrillero, Membrillo; Turkey: Ayva; Portugal: Marmelo, Marmeleiro.

It is a multi-stemmed spineless shrub with a height of 5-8 $\mathrm{m}$ and 4$5 \mathrm{~m}$ wide (Figure 1). It bears a bright yellowish pome fruit, acquiring 7-12 $\mathrm{cm}$ length and 6-9 $\mathrm{cm}$ across with a characteristic aroma and astringent taste. Quince fruit contains a plano-convex seed in significant number, organized in two vertical rows and the white/pink flowers with five petals bloom in spring with a diameter of $5 \mathrm{~cm}$ containing an inferior ovary with many ovules, 20 or more stamens and five styles. Its leaves are elliptical with dusky green above and whitish underneath color and have white hair on the surface with a length of about $6-11 \mathrm{~cm}$ and $5 \mathrm{~cm}$ across. Based on its shape of a fruit, three main varieties are mainly reported, namely; Pyriformis - Pear-shaped; Maliformis-Apple-shaped; Lusitanica-Lusitanian or Portugal quince with broader leaves and larger fruits. Compared to pearshaped, maliformis fruits have firm flesh with more astringent flavor. Caucasian region including, Armenia, Azerbaijan, Daghestan, Eastern and Southern Transcaucasia, Iran, Turkey, southwestern Russia, Turkmenistan, Western and Eastern Ante-Caucasus, Talysh and western Asia are the native region of its production and distribution, but now it is cultivated worldwide with Turkey being the largest producer of quince about $25 \%$ and China as the second largest producer followed by Iran, Argentina while Morocco produces the least (less than $10 \%$ of total production) (Postman, 2009).

\subsubsection{Name in different languages}

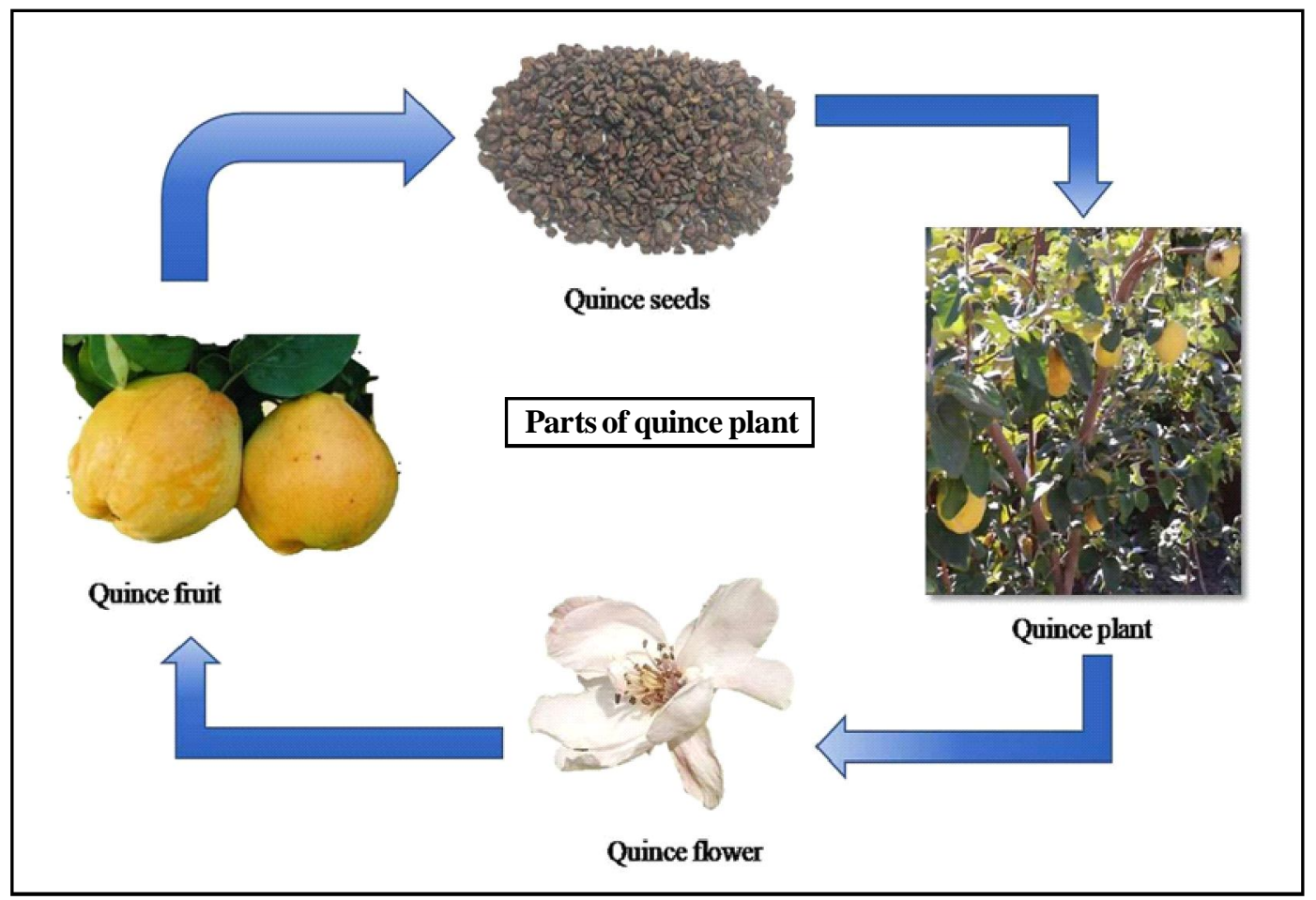

Figure 1: Various parts of quince utilized for pharmacological activities. 


\subsection{Economic botany}

\subsubsection{Culinary uses}

"Dulce de membrillo" is a popular quince paste in Spain, Chile and Argentina. Quince is not edible without prior to processing because of its hardness, astringency and acidity. Quince is already used for the manufacturing of marmalades, jams, jellies and some liqueur in food processing industry, and is applied in canning and for aromatic distillation. It is used in the production of most varied sweet products as its fruit contains a higher amount of pectin. Sensorial analysis of marmalades was evaluated in different quince cultivars and are divided into two groups: one with small granules and shiny surface along with typical aroma and flavor while the other one has intense aroma attributes to more granular texture (Ferreres et al., 2003); nevertheless reported to have a greater potential of acceptance by consumers. In our general Amazon search for quince product; it shows varieties of quince jam and marmalades, quince tea and quince pickle availability.

Furthermore, several published studies have acknowledged quince as an essential dietary source to improve health benefits due to their antioxidant, antimicrobial and antiulcerative action as it is enriched in amino acids, polyphenols and organic acids. Many studies have evaluated the processing effect on the phenolic content and antioxidant capacity at a laboratory scale on quince fruits (Baroni et al., 2018). For example: in Argentina unlike, as in Portugal, the whole quince fruit is squashed and heated and then solids were separated by using different sieves. Further, the pulp is blended with additives and sugar to produce jam as the final product. The discarded contain the skin and seeds remnants and some mesocarp. It has been published in several works that peel and seeds exhibit a higher level of polyphenol content than in fruits. The process of sustainability been obligatory, thus doing the projects for reuse or exploitation of present industrial waste relevant (Silva et al., 2004a).

\subsubsection{Cosmetics}

Quince leaves extract has been clinically evaluated for its soothing properties and anti-inflammatory abilities to improve skin comfort for sensitive skin. The leaf extract has also been tested on proinflammatory cytokines IL-89 and TNF- $\alpha$ (Echard et al., 2014). Many famous herbal-based cosmetics companies like Biotique Advanced Ayurveda (Bioquince seed nourishing Facial Massage Cream) and Lotus Herbals (Lotus Herbal Quincenourish Quince Seed Massage Crème) have recently launched a facial massage crème with quince seed extract as the main component.

\subsubsection{Traditional medicinal uses}

C. oblonga has been highly utilized in the conventional medicine system primarily by the Iranian traditional medicine practitioner since it has a broad range of nutritional and medicinal values. Islam Prophet Mohammad gave many narrations regarding the properties of quince like "Eat quince because it purifies the heart; it is perfect for lungs and cleans them". It is used prophylactically as well as therapeutically (Ashraf et al., 2016). It is believed that quince was the golden apple that Paris gave to aphrodite that result in the precipitating of the Trojan War and is the same golden fruit that tempted Eve in the Garden of Eden. Thus, it is considered to have a long history than the apple itself. At Roman's traditional wedding, the new bride will take a bite of quince as it is believed to add fragrance to their wedding, as it is associated with the symbol of fertility in Romans. Traditionally, quince leaves were also used as astringent and antiseptic. The decoction prepared from quince leaves has been used to treat fever, stomach cramps, cough, cold, diarrhea, insomnia and hyperglycemia while the roots were used as charmed against Scrofula. The fresh or dried flowers were effective for inflamed eyes (Tita et al., 2009).

Quince fruit is used in the food industry as a reservoir of pectin to cure irritable bowel syndrome (IBD) that protects colon damage and peptic ulcer (Hamauzu et al., 2008). Quince fruits are used as astringent, antiseptic, anti-inflammatory, hepatoprotective and also used to treat various ailments includes diarrhea, dysentery, hepatic disorders, leucorrhoea, haemoptysis, uterine hemorrhages and wounds (Fazeenah and Quamri, 2016). While the seeds were traditionally used as astringent, demulcent and as an emollient for the treatment of gastrointestinal (GI) disorders such as canker sores, constipation, diarrhea, dysentery, gum problems, intestinal colic and respiratory tract disorders including asthma, bronchitis, cough, sore throat and rhinitis. Mucilage of quince seed has also been used for the treatment of dermal wounds (Minaiyan et al., 2012). C. oblonga, the European quince is closely related to Chinese quince, Pseudocynodia sinesis and the fruit of flowering quince, Chaenomeles speciosa are considerably utilized in Chinese traditional medicine system to nurse ailments like arthritis, hepatitis, rheumatoid and prosopalgia (Huang et al., 2018).

\section{Pytochemistry}

\subsection{Nutritional value}

C. oblonga was reported to contain pectin, polyphenolics compounds, organic acids, many essential and volatile oils. The leaves of quince are analyzed for the essential oils showed that it contains oxygenated monoterpenes, aromatic aldehyde, sesquiterpene hydrocarbons and fatty acid. The quince fruits contain carbohydrate, lipids, protein and elevated quantity of mineral elements (Table 1) such as calcium, copper, sodium, iron, potassium, magnesium, zinc and manganese (Hegedûs et al., 2013).

\subsection{Chemical constituent}

C. Oblonga seeds contain tannins, sterols and triterpenes as a bioactive component that is responsible for quince antidiarrheal activity and also contain different amino acids, phenolics and, organic acids (Table 2). The cydonia plant also contain phenol peroxidase which is responsible for decolorizing carcinogenic aromatic dyes in the industrial wastewater. Essential oils, organic acids, phenolic compounds, ionone glycosides and tetracyclic sesterterpenes are isolated from distinct parts of the C. oblonga.

\subsubsection{Quince seeds}

A distinct phenolic profile of quince seed has been reported to contain 3-O-caffeoylquinic acids (3CQA), 5-O-caffeoyl quinic acids (5CQA), 3, 5-dicaffeoyl quinic acid (diCQA), 4-O-caffeoylquinic acids (4CQA), stellarin-2, leucenin-2, C-glucosyl flavones and apigenin derivatives (schaftoside, vicenin-2 and isoschaftoside) (Ishihara et al.,1986). Flavones are the major phytochemical constituents of the quince seeds phytochemistry (63-66\%) which include caffeoylquinic acids (35-37\%), 5CQA (19-24\%) and isoschaftoside (18\%) as prominent ones. Malic, D(-)-quinic, ascorbic, fumaric, citric and L-shikimic acid are the organic acids that are identified in quince seed phytochemical profiling. Oxalic acid is the only compound absent in seed extract. In quince seeds, the sum of quinic and malic acid of the 
total organic acid represents about 45 to 61 per cent, which is comparatively lower than that of the quince fruit and leaves. The total 21 free amino acids sum in quince seeds lies between 1.3 to 1.7 $\mathrm{mg} / \mathrm{kg}$, making quince seeds with higher concentration of total free amino acid than that present in fruits (ca. 0.8 for pulp and $1.0 \mathrm{mg} / \mathrm{kg}$ for peel). Glutamic acid, asparagine and aspartic acid are the 3 major free amino acids that that are found in higher quantity about 60 to
$75 \%$, while other amino acids are reported in smaller amount (Oliveira et al., 2007). Recently, ursolic acid, tormentic and $\beta$-daucosterol along with one new chromone have been isolated from quince seeds methanolic extract (Erdoðan et al., 2012). Fatty acid and sugar profile disclosed the presence of linoleic acid, 4-O-methyl glucose, palmitic, stearic, oleic, eicosanoic acids, D-xylose and D-glucose in quince seeds (Oliveira et al., 2008).

Table 1: Elements present in the fresh $C$. oblonga fruits in per $100 \mathrm{gm}$

\begin{tabular}{|l|l|l|}
\hline Main nutrition composition & Vitamin contents & Mineral elements \\
\hline Energy-176 kJ & Retinol (A)-5.5 $\mu \mathrm{g}$ & $\mathrm{Na}-92 \mathrm{mg} ; \mathrm{K}-189 \mathrm{mg}$ \\
Protein-0.6 g & Carotene- $0.03 \mathrm{mg}$ & $\mathrm{Ca}-66 \mathrm{mg} ; \mathrm{Mg}-10 \mathrm{mg}$ \\
Acid-0.9 $\mathrm{g}$ & Thiamine $\left(\mathrm{B}_{1}\right)-30 \mu \mathrm{g}$ & $\mathrm{Fe}-11 \mathrm{mg} ; \mathrm{P}-25 \mathrm{mg}$ \\
Carbohydrates-9.1 g & Riboflavin $\left(\mathrm{B}_{2}\right)-30 \mu \mathrm{g}$ & $\mathrm{Cu}-0.006 \mathrm{mg} ; \mathrm{Zn}-0.013$ \\
Water-86.9 g & Niacin $\left(\mathrm{B}_{3}\right)-0.2 \mathrm{mg}$ & $\mathrm{mg}$ \\
Ash-0.6 g & Ascorbic acids $(\mathrm{C})-13 \mathrm{mg}$ & $\mathrm{Mn}-0.002 \mathrm{mg}$ \\
Fiber-1.9 g & & \\
\hline
\end{tabular}

Table 2: Selected secondary metabolites reported in various parts of $C$. oblonga and its use in folk medicine

\begin{tabular}{|c|c|c|}
\hline Quince parts & Reported bioactive compounds & Folk medicine uses \\
\hline \multirow[t]{3}{*}{ Seeds } & Polyphenols & $\begin{array}{l}\text { The seeds are used for the treatment of } \\
\text { (Ashraf } \text { et al., 2016): }\end{array}$ \\
\hline & $\begin{array}{l}\text { 3-O-caffeoylquinic acids, 4-O-caffeoylquinic acids, 5-O- } \\
\text { caffeoyl, 3, 5-dicaffeoyl quinic acid, leucenin-2, 6-C-pen- } \\
\text { tosyl-8-C-glucosyl chrysoeriol, 6-C-glucosyl 8-C-pentosyl } \\
\text { chrysoeriol, apigenin derivatives (like vicenin-2, isoschaf- } \\
\text { toside, and schaftoside) and stellarin-2 (Silva } \text { et al., 2005). } \\
\text { Organic acids, fatty acids and sugar profile } \\
\text { Quinic acid, ursolic acid, tormentic acid, and } \beta \text {-daucosterol } \\
\text { and } 34 \text { carbon chromone (Ghopur } \text { et al., 2012). }\end{array}$ & $\begin{array}{l}\text { Gastrointestinal disorders (like constipation } \\
\text { and diarrhea). } \\
\text { Seed mucilage has been used for treating dermal } \\
\text { wounds. } \\
\text { Respiratory tract disorders (rhinitis, cold sore and } \\
\text { cough) }\end{array}$ \\
\hline & $\begin{array}{l}\text { Palmitic acid, linoleic acid, stearic acid, oleic acid and } \\
\text { eicosanoic acid (Daneshvand et al., 2012). } \\
\text { Sugars like L-arabinose, xylose, mannose, galactose and } \\
\text { D-glucose (Lindberg et al., 1990). } \\
\text { Others } \\
\text { Quince seed mucilage contains cellulose microfibrils } \\
\text { associated with glucuronoxylans (4-O-methyl- } \alpha \text {-D-gluco } \\
\text { pyranosyluronic and } \alpha \text {-D-glucopyranosyluronic residues } \\
\text { (Lindberg et al., 1990). }\end{array}$ & $\begin{array}{l}\text { Eg: Gencydo®, a mixture of aqueous quince and } \\
\text { lemon juice used in Europe for curing rhinitis } \\
\text { and asthma (Gründemann et al., 2011). }\end{array}$ \\
\hline \multirow[t]{2}{*}{ Leaves } & Polyphenols & Leaf decoction used in treating \\
\hline & $\begin{array}{l}\text { Caffeoylquinic acid derivatives, quercitin-3-O-rutinoside, } \\
\text { quercitin-3-O-galactoside, kaempferol-3-O-glycoside, } \\
\text { kaempferol-3-O-glucoside and kaempferol-3-O-rutinoside } \\
\text { (Oliveira } \text { et al., 2007; Benzartiet al., 2015). } \\
\text { Organic acids, fatty acids and sugar profile } \\
\text { D-(-)-quinic acid, oxalic acid, malic acid, L-shikimic acid } \\
\text { fumaric acid (Oliveira } \text { et al., 2008). } \\
\text { Others } \\
\text { Essential oils of leaves contain-(E)- } \beta \text {-ionone, (E, E)- } \alpha \text { - } \\
\text { farnesene, (Z)-3-hexenol, germacrene D, benzaldehyde, } \\
\text { (E)phytol and (Z)-3-hexenal (Erdoðan } \text { et al., 2012) }\end{array}$ & $\begin{array}{l}\text { dysuria, nervousness, insomnia, cough and cold, } \\
\text { fever, diarrhea, abdominal cramps and } \\
\text { hyperglycemia (Ashraf et al., 2016). }\end{array}$ \\
\hline \multirow[t]{2}{*}{ Fruits } & Polyphenols & Quince fruit or its extract have been \\
\hline & $\begin{array}{l}\text { Epicatechin, kaempferol, quinic acid and quercetin } \\
\text { derivatives (Wojdylo et al., 2013). } \\
\text { Caffeoylquinic acid derivatives, coumaroyl quinic acid } \\
\text { derivatives (Karar } \text { et al., 2014). }\end{array}$ & $\begin{array}{l}\text { reported for its } \\
\text { Anti-ulcerative properties of quince fruits have } \\
\text { been reported. }\end{array}$ \\
\hline
\end{tabular}




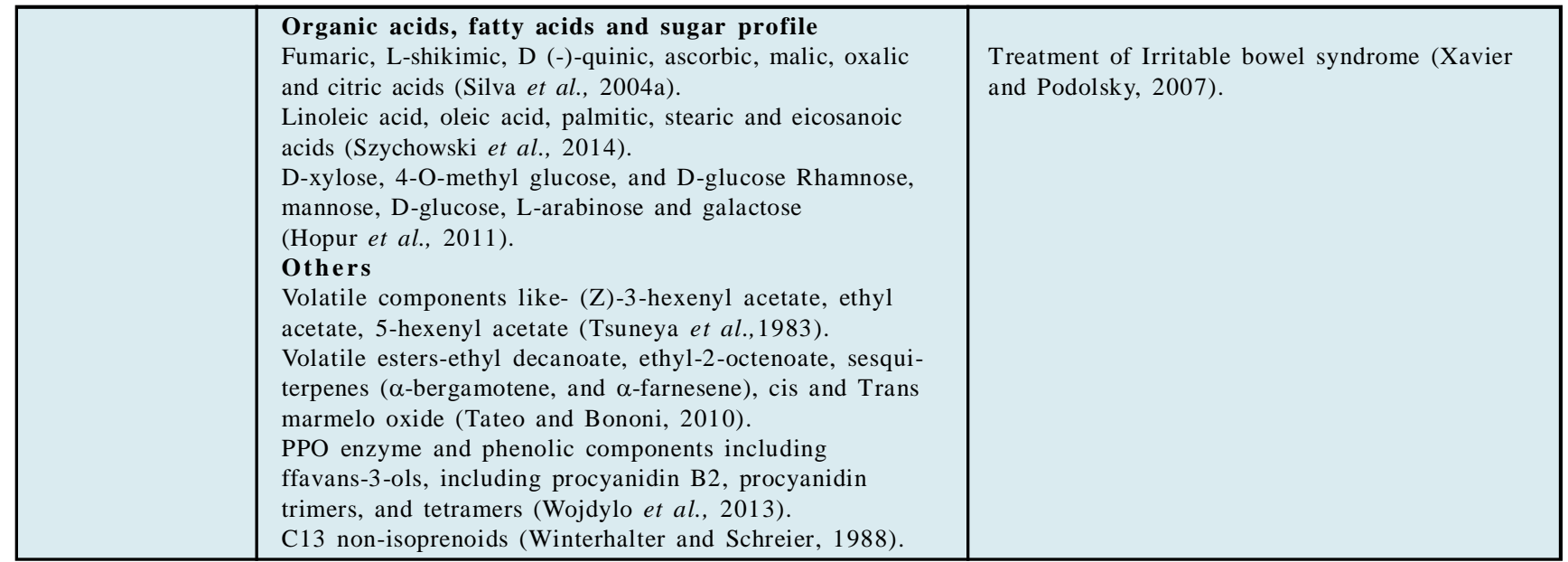

Table 3: Pharmacological attributes of C. oblonga

\begin{tabular}{|c|c|c|}
\hline Pharmacological activities & Phytochemicals involved & References \\
\hline $\begin{array}{l}\text { Quince fruit and seeds extracts (ethanolic, } \\
\text { acetonic and aquatic) can be used in controlling } \\
\text { antibacterial growth. }\end{array}$ & $\begin{array}{l}\text { Morphinan-3, 6- } \alpha \text {-diol, } 7,8 \text {-didehydro- } 4 \text {, } \\
5 \text {-áepoxy-17-methyl-, } 6 \text {-acetate, trimethyl } \\
\text { hydrazine, eucalyptol, camphor and } \\
\text { caryophyllene. }\end{array}$ & $\begin{array}{l}\text { Alizadeh } \text { et al. (2013) } \\
\text { Alizadeh } \text { et al. (2014) }\end{array}$ \\
\hline $\begin{array}{l}\text { Ethanolic extract of leaf of quince has a } \\
\text { superlative antifungal effect against } A \text {. niger. }\end{array}$ & - & \\
\hline $\begin{array}{l}\text { Quince hot water fraction shows an inhibitory } \\
\text { effect on type I allergy by suppressing IgE } \\
\text { production and IgE-mediated degranulation. }\end{array}$ & $\begin{array}{l}\text { Caffeoylquinic acids, quercetin glycosides } \\
\text { and kaempferol glycosides. }\end{array}$ & Shinomiya et al. (2009) \\
\hline $\begin{array}{l}\text { The phenolics are helpful to repair the colon } \\
\text { damage with IBD due to their antioxidant } \\
\text { and anti-inffammatory potential. }\end{array}$ & Quercetin, rutin and kaempferol. & Nijveldt et al. (2001) \\
\hline $\begin{array}{l}\text { Aqueous extract of } C \text {. oblonga is } \\
\text { reported to possess hypolipidemic, hepato- } \\
\text { protective, and reno-protective effects in } \\
\text { streptozotocin-induced diabetic rats and } \\
\text { improve some of the symptoms associated } \\
\text { with diabetes. }\end{array}$ & Polyphenols present in quince. & Mirmohammadlu et al. (2015) \\
\hline $\begin{array}{l}\text { Quince aqueous extract shows beneficial effects } \\
\text { against doxorubicin cardiotoxicity, mediated } \\
\text { by attenuating mitochondrial dysfunction. }\end{array}$ & $\begin{array}{l}\text { 5-O- caffeoylquinic acid shows immense } \\
\text { cardio protective potential. }\end{array}$ & $\begin{array}{l}\text { Gholami et al. (2017) } \\
\text { Vaez et al. (2014) }\end{array}$ \\
\hline $\begin{array}{l}\text { Quince leaf and fruit, aqueous extracts reported } \\
\text { having anti-thrombotic and anti-hyperten- } \\
\text { sive activities in mice. }\end{array}$ & - & Zhou et al.(2014) \\
\hline $\begin{array}{l}\text { Hydroalcoholic and polyphenolic extracts of } \\
\text { Quince are reported to have geno protective } \\
\text { effects. }\end{array}$ & $\begin{array}{l}\text { The phenolics such as quercetin, rutin, and } \\
\text { kaempferol are helpful to repair the colon } \\
\text { damage with IBD due to their antioxidant } \\
\text { and anti-inffammatory potential. }\end{array}$ & Mousavi et al. (2015) \\
\hline $\begin{array}{l}\text { Quince leaf decoction (C. oblonga Mill.) } \\
\text { shows spermatogenesis from damage } \\
\text { induced by hypercholesterolemia in vivo. }\end{array}$ & Phenolic acid and flavonoids content. & Ashrafi et al. (2012) \\
\hline
\end{tabular}

\subsubsection{Quince leaves}

Quince leaves were found to contain derivatives of chlorogenic acids, kaempferol and quercetin, with 5CQA in highest concentration of about $36.2 \%$, quercitin-3-O-rutinoside with about 21.1 per cent and 12.5 per cent of K3R (kaempferol-3-O-rutinoside) (12.5\%) (Tsuneya et al., 1983). Quince plant leaves are reported to be rich with $72.7 \%$
D-(-)-quinic acid followed by oxalic acid, citric acid and malic acid along with a presence of minute fraction $(<1 \%)$ of shikimic and fumaric acids. According to Dzhan, a study on a fatty and organic acid composition like oxalic, citric, palmitic and linoleic acid is reported in higher content (Dzhan, 2016). It was also observed that quince leaves possess relatively higher acid contents when collected in June 
and August than in October (Tateo and Bononi, 2010). Furthermore, quince leaves analysis revealed the presence of 40 different essential oils, aromatic aldehyde, fatty acids, sequesterpene hydrocarbons (benzaldehyde, hexadecanoic acid, linalool, $(E)$ - $\beta$-ionone and germacrene D) and oxygenated monoterpene. Essential oils that are isolated from quince leaves are also reported to contain (Z)- $\beta$ Farnesene (4.8\%), germacrene D (8.6\%), benzaldehyde with $4.9 \%$, (Z)-3-hexenal (3.0\%) and (E) phytol (3.1\%) (Winterhalter and Schreier, 1988). 2-methylbutanoate is one of the essential components found in quince leaves (Velièkoviæ et al., 2016).

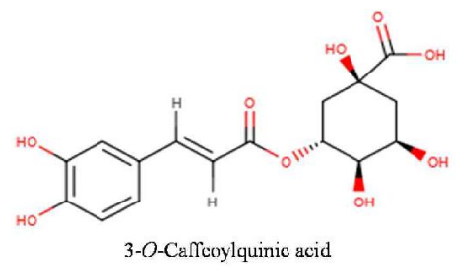

3-O-Cafeoylquinic acid

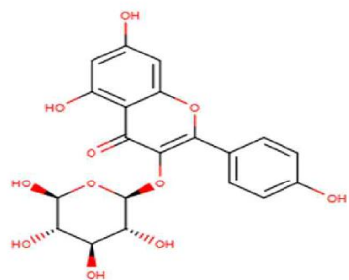

Kaemfferol-3-O-glucoside

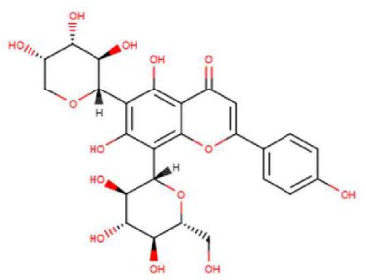

Isoschaftoside

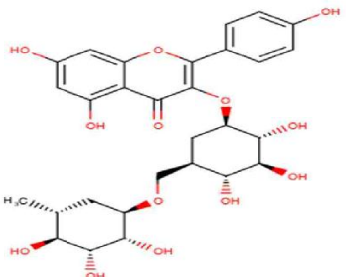

Kaempferol-3-O-rutinoside

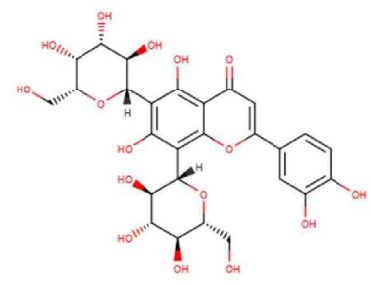

Lucenin-2

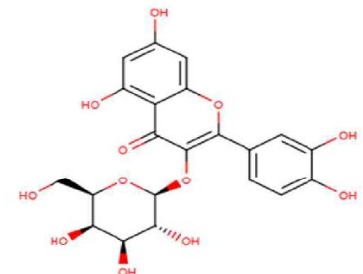

Quercetin-3-O-galactoside

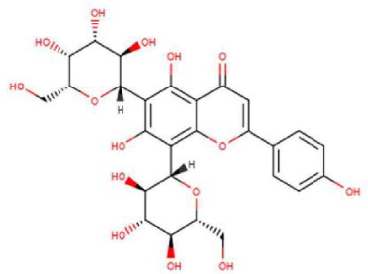

Vicenin-2

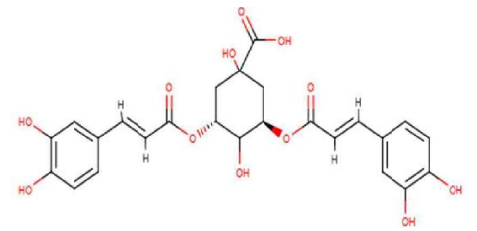

3,5-O-Dicalfcoylquinic acid

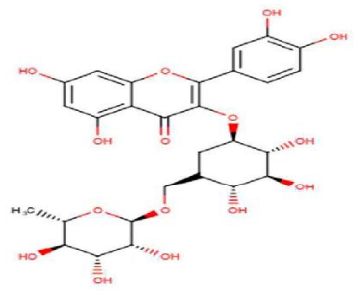

Quercetin-3-O-rutinoside

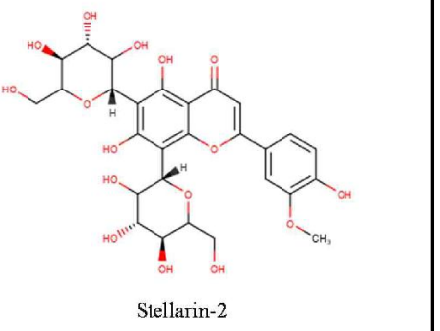

Figure 2: Various polyphenolic compounds found in C. Oblonga (Quince).

\subsubsection{Quince fruit}

Silva and his coworkers have disclosed the phenolic profile present in quince fruits such as CQA $(79.6 \mathrm{mg} / \mathrm{kg})$ and $5.5 \mathrm{mg} / \mathrm{kg}$ of rutin. Quince peel provides higher concentration of CQA about $291.6 \mathrm{mg} /$ $\mathrm{kg}$, kaempferol-3-rutinoside, kaempferol 3-glucoside/glycoside (92.9 $\mathrm{mg} / \mathrm{g}$ ) and it also contains two acetylated glycosides of kaempferol and p-coumaric acid acetylated quercetin glycosides, while the pulp contains 3CQA, 4CQA, 5CQA, diCQA, rutin and quercitin-3galactoside. On the other hand, the peel is reported to contains kaempferol derivatives (Silva et al., 2002a). The phenolics present in peel extract are five times higher in amount than that of the pulp. $5 \mathrm{CQA}$ is a significant phenolic present in quince fruit while stellarin2 is rich in seeds. The phenolic content of fruit jams produced from both peeled and unpeeled quince fruit was also analyzed, which inferred that jam prepared from unpeeled fruit contain greater amount of flavonoids (19\%) than from peeled jams (3\%). In another study, HPAEC revealed presence of various sugar derivatives in three quince cultivars (Triumph, Vranjska, and Leskovacka) like maltose, ribose, isomaltose, rhamnose, fructose, sucrose, D-glucose, D-sorbitol, Dtrehalose and D-galactitol. Quince peel and pulp both contain similar amino acids and a lower concentration of glutamic acid, tryptophan and histidine due to their thermal degradation (Silva et al., 2002b). Some studies have also shown for the residence of pectin in the $C$. oblonga fruit (Silva et al., 2004b).

\section{Important bioactive compounds of $C$. oblonga}

Extensive exploration has been executed to provide the metabolic profile $C$. oblonga, which constitutes many promising bioactive phytochemicals suitable for the prevention and care of many diseases, namely; antiallergic, in the control of asthma and rhinitis, diabetes mellitus, cardiovascular complaints, respiratory and gastrointestinal problems and anticarcinogens. In this regard, Rahimi et al. (2010), have reported that quince phenolic composition has the strongest antioxidant effects and provides clear evidence of its medicinal importance. Presently, it has been established that the generation of free radicals causes hemolysis are related to various ailments like Alzheimer's disease, Parkinson's disease, arthritis, arteriosclerosis, cancer and diabetes. The antioxidant potential of the phenolics present in Cydonia fruit are reported to help in the treatment of colon damage with IBD (Márcia et al., 2010). Alesiani et al. (2010), have isolated and tested 59 phytochemicals for their antioxidant capacity from quince peels from which quercetin and quercetin 3-O-rutinoside is 
the most active antioxidants. The polyphenol compounds that are found in significant concentration in quince products (Figure 2) are caffeoylquinic derivatives like 3CQA, 4CQA, 5CQA and diCQA along with quercetin and kaempferol while the data indicating polyphenol 5CQA (measuring from $29 \%$ to $57 \%$ ), to be the main compound isolated from pulp and peel (Yildirim et al., 2001).

\subsection{Caffeoylquinic acid (CQA) and its derivatives}

CQA derivatives are reported to reveal distinct physiological functions such as antioxidant activities, radical scavenging activities, antiproliferative and anticancerous activities. It was stated that the consumption of chlorogenic acid might enhance antioxidant status leading to increased colon motility and decreased colorectal cancer risk (Vitaglione et al., 2012). For example, chlorogenic acid (ChA), diCQA and 4,5-diCQA were identified as the main compounds responsible for antioxidants activity (Murayama et al., 2002), while ChA acid stimulates apoptosis by inhibiting the leukemia cell line proliferation (Liu et al., 2013). It causes apoptotic cell death in human leukemia cells U937 by inducing the expression of caspases and thus, stimulating mitochondria-dependent pathways (Yang et al., 2012); and it also suppresses invasion of hepatoma cell without affecting the proliferation of cell (Yagasaki et al., 2000).

A549 cells of human lung cancer when treated with ChA shows a decreased level of cell proliferation, reduced $\mathrm{Bcl} 2$ expression but enhanced expression of Bax, caspase 3 and annexin $\mathrm{V}$ expression. It also induces the expression of p38, MAPK and JNK gene and reduces the expression of stem cells associated gene markers such as SOX2, NANOG and POU5F1 (Yamagata et al., 2018). ChA and its derivatives (di-and tri-caffeoylquinic acid and caffeic acid) have been reported to have dose-dependent depressed HL-60 cancer cell growth (Kurata et al., 2007). Murad et al. (2010), have studied the effect of caffeic and 5CQA on the cell growth, cell cycle and apoptosis in colorectal adenocarcinoma HT-29 cell line. It is also observed that these compounds not only effect HT-29 cell viability but also increases the cell apoptosis rate and promote certain changes in the cell cycle. An in vitro study done by Hou and his colleagues showed that chlorogenic acid-treated human colon cancer cell line has reduced the cell viability and increased the reactive oxygen species generation. The activities of these ChA polyphenols suggested that they could be utilized as a potential cancer therapeutic agent (Hou et al., 2016).

\subsection{Kaempferol and its glycosides}

Epidemiological evidence has proposed that ingestion of a diet rich in kaempferol may minimize the chance of developing various cancers like liver cancer, colon cancer and skin. Kaempferol and its glycosides are gaining the attention of researchers as it regulates distinct features of cancers such as cell cycle arrest (Ramos, 2008), apoptosis (Luo et al., 2010; Kim et al., 2008), inflammation (Ulrich et al., 2006) and also reported to inhibit the metastasis activity of breast and medulloblastoma cancer cells (Labbé et al., 2009; Phromnoi et al., 2009). Kaempferol has dose-dependent anticancer effects without toxicity on Panc-1, Miapaca-2 and SNU-213 cell lines which decreases the proliferation of pancreatic cancer cells by increasing apoptosis at a relatively low dosage and this activity was regulated by inhibition of the Src, ERK1/2 and AKT associated pathways of EGFR (Lee and Kim, 2016).

Kaempferol treated K562 and U937 cells shows the de-phosphorylation of Akt at residue Ser473 and Thr308, inhibition of PI3K (Marfe et al., 2009), it also decreases the level of peroxynitrite, superoxide anion and hydroxyl radical levels and trigger the activation of proteins involved in apoptosis such as caspase-3/7/9 and PARP in HepG2 cell line. It can also remarkably inhibit the proliferation of $\mathrm{T}$ cells mediated activation by Tumor necrosis factor- $\alpha$ and concanavalin A (Con A) which in turn increases radical scavenging ability of DPPH and ABTS and production of NO or ROS in LPS-induced RAW 264.7 macrophage cell (Wang et al., 2018). K3R along with polyphenol kaempferol 3$\mathrm{O}$-glucoside are reported to have hepatoprotective effects on mice injured liver induced via $\mathrm{CCl}_{4}$ and it significantly restore the GSH level and normal catalase and SOD activities (Wang et al., 2015).

\subsection{Quercetin and its glycosides}

Extensive studies have shown the anti-proliferative activity of quercetin and its glycosides (You et al., 2010). Studies have been documented on rutin's anticancer potential, such as inhibiting cancer cell proliferation, angiogenesis and/or metastasis of colorectal cancer by arresting cell cycle and inducing apoptosis (Araújo et al., 2011). Rutin is also proven to be useful in radioiodine therapy as an adjuvant (Gonçalves et al., 2013). In an analysis, rutin $(120 \mathrm{mg} / \mathrm{kg}$ dose) treatment results in a substantial reduction in the size of human leukemia HL-60 tumor (Liu et al., 2013). Furthermore, Chen et al. (2013), demonstrated chemotactic ability and anti-neuroblastoma effect of rutin by inhibiting the LAN-5 cells growth. It also reduces the expression of BCL2 along with the secretion of TNF- $\alpha$ and the level of MYCN mRNA. Synergistic effects of the extract of apple and polyphenol Q3G (quercetin-3-glucoside) have been reported to enhance the anti-proliferative action in MCF-7 cancer cell (Yang and Liu, 2009). HepG2 cells treated with Q3G in a time and dose dependent manner, observation indicated the $\mathrm{S}$ phase cell cycle arrest causing inhibition of cell proliferation. Additionally, Q3G displayed a strong ability to inhibit DNA topoisomerase II (Sudan and Rupasinghe, 2014)

In an independent study, the polyphenol rutin has been comprehensively analyzed for its hepatoprotective ability in BALB/ c mice rutin therapy allayed liver toxicity and neurotoxicity induced by oxaliplatin. Its hepatoprotective activity was suggested by the protection of mechanical allodynia and histopathological (Schwingle et al., 2014). Khan and his coworkers have also shown rutin's protective effect in mice liver injuries induced by carbon tetrachloride $\left(\mathrm{CCl}_{4}\right)$ in rats (Khan et al., 2012).

\subsection{The C-glycosyl flavones}

They are reported to be an effective anticancer agent against Hep-G2 (IC $50: 15.3 \mu \mathrm{g} / \mathrm{ml}$ ), HT-29 ( $\left.\mathrm{IC}_{50}: 24.2 \mu \mathrm{g} / \mathrm{ml}\right)$ and moderately effective against MCF-7 breast cancer cells $\left(\mathrm{IC}_{50}: 28 \mu \mathrm{g} / \mathrm{ml}\right)$. C-glycosyl flavonetreated Hep-G2, HT-29 and MCF-7 cells showed a decrease in Bcl-2 level and marginally increased Bax levels. The anticancer activity of C-glycosyl flavone against MCF-7, HT-29 and Hep-G2 may be due to arrest of the cell cycle, angiogenesis suppression and induction of apoptosis probably through CDK6 inhibition (Bevara et al., 2018). It has also been reported for its many prophylactic properties such as anti-inflammatory, antioxidant, anticancer and also hepatoprotective ( $\mathrm{Ku}$ and $\mathrm{Bae}, 2016)$. In a reported study, vicenin-2 induces apoptosis and inhibits the signaling of Wnt/ $\beta$-catenin in the HT-29 cancer cell line (Yang et al., 2018). It has been reported that vicenin2 suppresses angiogenesis by decreasing VEGF expression in prostate cancer and in preclinical models, its proven to be effectively absorbed when orally administered which has been associated with tumor 
regression (Singhal et al., 2017). Another in vitro research conducted by Nagaprashantha et al. (2011), shows the anti-cancerous activity against cell lines of PC-3, DU-145 and LNCaP by targeting the pathways of EGFR/Akt/mTOR/p70S6K alongside decreasing CDK4, hTERT, c-Myc, cyclin D1, cyclin B1 and PCNA and also shows to have synergetic effect with docetaxel.

\subsection{Organic acids}

Quince is characterized by the presence of relative amounts of quinic acid, fumaric acid, oxalic, citric and shikimic acid (Oliveira et al., 2008). For multivalent cations, oxalic acid has the most striking chelating ability and the most prominent water-soluble antioxidants ascorbic acid is frequently found in vegetable oils. Carboxylic acids include malic, citric, succinic, tartaric and hydroxy glutaric also have the ability to chelate metal which is responsible for its antioxidant activity. Therefore, they are considered as "preventive" or synergistic compounds with antioxidant potential (Seabra et al., 2006).

\section{The pharmacological potential of $C$. oblonga against cancer cure and treatment}

Central pharmacological effects of $C$. oblonga, which are reported in several studies are summarized in the Table 3.

\subsection{Antioxidant potential and antihemolytic effects of $C$. oblonga}

The fractionated phenolic and organic acid of methanolic extracts of C. oblonga jam and of whole fruit were evaluated for the screening of their antioxidant potential by using diode array detection (HPLC) and HPLAC/UV analysis. The study shows that the phenolic fractions possess significantly stronger potential of scavenging free radical and greater antioxidant activity than organic acid fractions (Silva et al., 2004b), while the seed extract's phenolic fraction possess the significantly greater antioxidant activity when the $50 \%$ inhibition concentration of the quince leaves, seeds, pulp and peel were correlated with the content of CQA. Study reported by Magalhães and his colleagues (Magalhães et al., 2009), has evaluated the antioxidant potential of the isolated phenolics from the methanolic preparation of quince leaves, fruits and seeds for their ability to inhibit the oxidative hemolysis induced by APPH of human erythrocytes and to quench DPPH (2,2'-diphenyl-1 picrylhydrazyl). Similarly, the extract of quince peel $\left(\mathrm{EC}_{50}\right.$ of $\left.0.8 \mathrm{mg} / \mathrm{ml}\right)$ and pulp $\left(\mathrm{EC}_{50}\right.$ of $\left.0.80 \mathrm{mg} / \mathrm{ml}\right)$ also showed DPPH scavenging activities, while seed extract's antioxidant activity exhibit much lower $\left(\mathrm{EC}_{50}\right.$ of 12.2 $\mathrm{mg} / \mathrm{ml}$ ) potential. In another study, 59 phytochemicals were isolated from quince peels are tested for their antioxidant capacity in which quercetin and rutin are the most active antioxidants (Alesiani et al., 2010). Among the quince phenolic extracts evaluation, the quince seed extract possesses a significantly higher antioxidant potential with inhibition constant $(50 \%)$ of $0.1 \mathrm{mg} / \mathrm{ml}$, accompanied by the phenolic extract of peel with $50 \%$ inhibition constant of $0.4 \mathrm{mg} / \mathrm{ml}$ and then lastly the extract of pulp contains comparatively lowest activity with $1.0 \mathrm{mg} / \mathrm{ml}$ of $\mathrm{IC}_{50}$ (Silva et al., 2005). Quince seed is reported for their antioxidant activity due to the presence of apigenin derivatives and luteolin. However, presence of chrysoeriol increase the flavonoids antiradical activity due to the presence of methoxyl substituent in certain positions (Burda and Oleszek, 2001).

To the comparative study conducted between leaf of quince and green tea for evaluation of the antioxidant potential, quince leaf demonstrates significantly higher reducing power but have notably lower DPPH scavenging activity than that of green tea extract. 5CQA, the major phenolic compound of quince leaf extract is responsible for remarkably higher reducing power which can be used as a therapeutic agent against free radicals than green tea. The leaf methanolic extract of both quince and green tea were also evaluated for their anti-hemolytic activity and the analysis shows that both significantly protected the AAPH-induced hemolysis in a dose dependent manner following a lag time of $2 \mathrm{~h}$ in erythrocytes (Costa et al., 2009).

Scavenging and reductive power along with the anti-lipoperoxidation activity of lipophilic QAFE (quince aqueous fermented extract) and QWE (quince wax extract) were also investigated. Study reported shows that QAFE has an effective scavenge ability against DPPH free radicals with $\mathrm{ID}_{50}$ of $68.80 \mu \mathrm{g} / \mathrm{ml}$ and anion superoxide radicals $\left(\mathrm{ID}_{50}=73.7 \mu \mathrm{g} / \mathrm{ml}\right)$, while QWE is comparatively more at preventing the thiobarbituric reactive species $\left(\mathrm{ID}_{50}=48.9 \mu \mathrm{g} / \mathrm{ml}\right)$ formation than QAFE (Pacifico et al., 2012). The nutraceutical formulation, chewing candy (CC) produced using juice and juice by-products of quince (C. oblonga) and sea buckthorn (Hippophae rhamnoides) was reported to have antimicrobial activity especially by buckthorn juice and quince juice against Bacillus and Proteus mirabilis pathogen. Moreover, the addition of juice and juice by-products increased the chewing candy's antioxidant potential by five times (Lele et al., 2018). Similarly, a cookie containing Japanese quince fruit (0-9\%) are reported to have higher contents of volatile compounds which gives it an antioxidant attributes and also exhibited 2-3.5-fold higher radical scavenging properties compared to control cookies (Antoniewska et al., 2019). The biochemical and antioxidant activity evaluation of Japanese quince and its products like candied fruit slices illustrated the high amount of vitamin $\mathrm{C}$ and higher phenolic compounds resulting in significant antiradical activity (Rubinskienë et al., 2014).

\subsection{Anticancer and antiproliferative potential of $C$. oblonga}

Leaf and fruits (peel, pulp, and seed) were investigated for their antiproliferative properties in kidney and colon cancer cells (Márcia et al., 2010). Leaves methanolic extract showed anti-protective activity against colon cancer cells of human, while no significant activity was noticed against renal carcinoma cells $\left(\mathrm{IC}_{50}=239 \pm 43.2 \mu \mathrm{g} / \mathrm{ml}\right)$. While the extract of quince fruit and seed exhibited a remarkable antiproliferative activity towards renal adenocarcinoma (highest concentration $500 \mu \mathrm{g} / \mathrm{ml}$ ), but often no effect on colon cancer cell growth. Assessment of QAFE and QWE were evaluated against HeLa, A549 and HepG2 cancer cell lines and both the formulated exits imposed a distinct effect on the cell's proliferation. The noteworthy point of this analysis is that QAFE is more potent than QWE, but often it tended to have a highly contingent effect on exposure time (Pacifico et al., 2012).

Phytochemicals (namely caffeoylquinic acids, quercetin and rutin) isolated from the quince peels were investigated for their antiproliferative activities targeted against B16-F1 murine melanoma cells in which ursolic acid is the most active phytochemicals with $\mathrm{IC}_{50}$ of $10.2 \mu \mathrm{M}$ (Alesiani et al., 2010). A study reported the effect of aqueous quince fruit extract on rat's hepatocellular carcinoma induced by diethylnitrosamine (DEN) (Adiban et al., 2019). An interperitoneal injection of DEN $(200 \mathrm{mg} / \mathrm{kg})$ was used to induce hepatocellular carcinoma for two weeks as an initiator, followed by $30 \mathrm{mg} / \mathrm{kg}$ oral administration of 2-acetylaminofluorene for two weeks daily as a 
promoter. Quince treated rats shows significant reduction in the level of serum biomarkers of injured liver and cancer. Moreover, the in vivo antioxidant activity of QAFE exhibited increased glutathione (GSH) level and prevents lipid peroxidation in the DEN-treated injured liver tissues rats.

\subsection{Wound healing}

In Iranian folk medicine, quince seeds mucilage (QSM) is used for treating skin wound as a folk remedy (Tamri et al., 2014). Fibroblasts plays pivot role in degrading the clots in the whole process of tissue repairing and also in the contraction of a wound as it is involved in the extracellular matrix (ECM) and collagen development (Stortelers et al.,2008). The effect of QSM was evaluated by Ghafourian et al. (2015), studied the mechanism of wound healing on the proliferation of human skin fibroblasts by the effect of QSM at different concentrations from 50 to $400 \mu \mathrm{g} / \mathrm{ml}$, respectively, on human skin fibroblast cell line after 12, 24, 48 and $72 \mathrm{~h}$. The micro-culture tetrazolium assay cleared that QSM geared up the human fibroblast cells proliferation even at low concentration $(50 \mu \mathrm{g} / \mathrm{ml})$ after $48 \mathrm{~h}$. In a double-blind clinical trial, 34 patients referred to dermatology for benign lesions to biopsy or surgery, reported effective topical wound healing containing quince seed mucilage 10\% (Moosavi et al., 2006). Sabale et al. (2012) reported the wound healing activity of quince leaves. The evaluation of percentage yield (10.97\%) and content of moisture $(4.38 \%)$, proteins $(20.9 \%)$, and ash $(8.24 \%)$ of quince mucilage were calculated (Fekri et al., 2008).

In another study, quince seeds ethanolic extract was evaluated on wounds of second degree burn on mice for healing and the results shows that $99.5 \%$ of wound healing produced by the $1 \%$ of QSM containing ointment as compared to sulfadiazine standard with 92.97\% wound healing ability (Tajoddini et al., 2013). Similarly, acetonic and methanolic extracts of quince seeds along with the silver nanoparticles of QSM were reported to be effective against $S$. aureus infected wounds (Alizadeh et al., 2013). An in vivo study has also justified the effectiveness of QSM for skin wound healing on white Iranian rabbits by applying quince seeds mucilage cream (QMC) at 5 , $10,20 \%$ in eucerin base and shown that wound treated with QMC with 20\% QSM in cream healed completely in 13 days (Tamri et al., 2014). Jouki and his colleagues (Jouki et al., 2014) prepared a dermal patch of quince mucilage and were evaluated for mechanical, physical and thermal parameters including their microstructures analysis along with its antibacterial and antioxidant capacity by incorporation of oregano essential oils $(1,1.5$, and $2 \% \mathrm{v} / \mathrm{v})$.

Hemmati et al. (2010) investigated the wound healing effect of QSM on T-2 toxin induced skin lesions of a rabbit. An experimental model was categorized into six groups $(n=6)$; groups 1 : received the positive controls (poison), group 2: received negative control (Eucerin), groups 3 to 5 : received different concentration of mucilage treatment $(5,10$, and $15 \%$, respectively) in eucerin and group 6: received T-2 toxin solvent (methanol). The toxin, T-2 was used to induce dermal toxicity prepared by dissolving $100 \mu \mathrm{g}$ of toxin in methanol $(12 \mu \mathrm{l})$ and the prepared cream was applied twice on skin with interval of 24 hours. Erythema and inflammation were observed in groups received toxin, but less inflammation was observed in rabbits treated with mucilage of $10 \%$ and $15 \%$ on the third day. The damaged skin completely healed with $15 \%$ quince seed mucilage with no inflammation or redness was observed on the eighth day and the grown hairs on normal skin was the outcome of quince seed mucilage treatment. The observation of this study proposed following possible mechanisms for healing effects of QSM: (i) preventing T-2 toxin-mediated impaired protein synthesis; (ii) serve as a growth factor and antioxidant agent; (iii) act as a barrier between skin and T-2 toxin along with evaporation of dropping water; (iv) promoting the development of granulation tissue and induces circulation of blood; (v) counter balancing of the T-2 dermal toxicity; and (vi) enhancing collagen development and affecting activities of fibroblast.

\subsection{Ultraviolet protective effects}

A study reported by Osman et al. (2010) on African catfish (Clarias gariepinus), documented the negative impacts of UVA (Ultraviolet A) and recognized impact of quince leaf extract in preserving and/or reduction of such adverse effects (Osman et al., 2010). The outcome of the reported study shows a remarkable decrease in the counts of red and white blood cells and UVA exposed hemoglobin and hematocrit as compared to control $(p<0.05)$. The biochemical parameters including aspartic aminotransferase, alanine aminotransferase, blood glucose, blood cholesterol, plasma creatinine and total plasma protein, exhibits a remarkable elevation in the catfish blood on UVA exposure. In conclusion, this study shows the ability of the methanolic extract of $C$. oblonga leaf to prevent the red blood cells from the UVA induced damage and hematotoxin stress. Furthermore, it resulted in the immune system enhancement of the Clarias gariepinus, represented by notable increase in WBCs and lymphocytes number $(p<0.05)$. Sayed et al. (2013) documented in his research the beneficial protective antioxidant function of $C$. oblonga leaf extract to discourage and/or rebuild the histopathological changes caused by UVA (Sayed et al., 2013).

\section{Discussion}

Cancer is a frightful disease, with a leading cause of mortality and morbidity across the world regardless of tools provided for cancer prognosis, treatment and treatment measures (Siegel et al., 2020). The expensive, emotionally and physically exhaustive diagnosis and treatment of cancer stirs the emotional stress and fear in cancer patients and causes them to seek out support from alternate therapies (Alsanad et al., 2016). According to the WHO, approximately $80 \%$ population in world rely on traditional medications for the healthcare needs and about 70-95\% of populations in developing countries depends on herbal remedies for a primary health care (Robinson and Zhang, 2011). In the recent years, therapeutic potential of herbal medications has attracted researchers' attention owing to their market potential and presently presumptuous billion-dollar worldwide market (Williamson et al., 2020). The advancement of many plants derived bioactive compounds to clinical trials have paved the trail for the medicinal herb researches. For example, flavopiridol derived from plant Amoora rohituka is in advanced stage of clinical trials for the treatment of various types of cancers (Deep et al., 2018) and $B$. monnieri is also investigated for its compound name bacoside $\mathrm{A}$ (John et al., 2017).

C. oblonga, distinguished by its antibacterial, anticancer, antioxidant, antiviral and antiulcerative properties, acknowledged as a conventional and significant determinant of health development compounds (Sut et al., 2019). The various reported studies suggested the presence of phenolic compounds especially hydroxycinnamic acids derivatives are the main reasons for these activities, possibly associated with health benefits (Alam et al., 2016). Caffeoylquinic acids that can be found in all parts of quince, capable of suppressing cancer cell development and stimulate programmed cell death (Márcia et al. 
2010). Quince seeds, often regarded as a waste in the production of various quince-based products like jams, jellies and marmalades can also be exploited for their promising bioactive compounds like derivatives of CQA, quercetin and hetrosides of kaempferol present in high level. These compounds of quince can be exploited for cancer prevention and treatment, as many studies suggested their ability to inhibit the growth factors like interleukin-2 and interferon- $\gamma$, extracellular signal (like NF- $\mathrm{KB}$ serine/threonine protein kinase and regulate protein kinase1/2) and are well established for alleviating oxidative damages to cellular DNA, lipids and proteins due to their radical scavenging ability (Aggarwal et al., 2006). Quince ethanolic leaf extracts shown significant reduction of blood pressure (dosedependent) and also reported to have protective effect on rabbit testes and spermatogenesis against hypercholesterolemia damage (Ashrafi et al., 2012). Furthermore, many studies are reported about the combination of pharmaceutical drugs and herbal medicine exerts synergistic interaction via enhancing the therapeutic effects of drugs or antagonism to reduce side effects (Zhou et al., 2016). The phenolic molecules such as quercetin, catechin kaempferol and procyanidin have revealed promising antioxidant and antitumor effect on colon cancer cell lines (Vuonget al., 2014; Alonso-Castro et al., 2013; Dinicola et al., 2012). The phenolic extract of $C$. oblonga peel and pulp have shown inhibitory effect in human colon adenocarcinoma (LS174 cells) and also some promising synergistic with 5-fluorouracil by inhibiting the pro-survival signaling pathway (NF- $\kappa \mathrm{B})$ and suppressing the expression of various cellular markers involved in cell cycle (cyclin D1) and angiogenesis (VEGF) (Riahi-Chebbi et al., 2016).

There is some prejudice associated about the safety and efficacy of herbal products. Like modern drugs, they can also cause allergic reactions and side-effects, but relative to modern therapeutic agent counterparts, much less. Both medicine system can function beneficially and can be used safely if utilized with knowledge and care (Awodele et al., 2018). Many experimental analyses have been undertaken on the chemical composition of $C$. oblonga fruit, seed and leaf; however, the detailed effect of $C$. oblonga compounds and its therapeutical properties is poorly studied. Clinical studies and detail studies on pharmacokinetic activities of quince is required, also including the assessment on its herb-drug interaction which is essential to prevent unwanted adverse effects or therapeutic failure.

The role of the optimal diet for those wishing to prevent cancer, its treatment and reoccurrence are promoted each year, reporting studies about various foods, phytochemicals, and nutrients and their uses as an alternative and complementary approach for prevention and treatment.

\section{Conclusion}

Currently, preventive strategies have been gaining attention, in this context. The use of functional foods with chemopreventive compounds, which included anticarcinogenic, antioxidants, and antiinflammatory effects such as the consumption of chlorogenic acids (CGAs) is associated with reduced possibilities of chronic diseases including cancer. Our plant in review, C. oblonga, an impressive and affordable natural reservoir of metabolites with outstanding therapeutic activities and ethnobotanical uses. Pectin is found in abundance in the quince derived products like jam and jellies in the food industry. Quince is also popular for its biological activities, namely antiproliferative, anticancerous, antihemolytic, reno- protective, hepatoprotective, genoprotective, anti-inflammatory, antidiabetic, antioxidant, cardioprotective activities and quince leaves protective effects has been established on male fertility has been established. Quince fruits and leaves constitute promising phytochemicals, namely; caffeoylquinic acids, quercetin and kaempferol heterosides, which are reported for their antioxidant, anti-proliferative, hepatoprotective and other anti-carcinogenic activity making it a novel source of cancer prevention and care. However, more clinical studies and researches are required to gain insight into its pharmacokinetics, efficacy and safety of the plant(s) extract for various disorders and diseases. Hence, there is an enormous necessity to isolate and examine the possible active compounds from $C$. oblong $a$ for the advancement of secure, new and affordable drugs.

\section{Acknowledgements}

The authors would like to thank the Faculty of Doctoral Studies and Research, Integral University for providing the manuscript communication number (IU/ R\&D/2020-MCN00789).

\section{Conflict of interest}

The authors declare no conflict of interest related to this article.

\section{References}

Adiban, H.; Shirazi, F.H.; Gholami, S.; Kamalinejad, M.; Hosseini, S.H.; Noubarani, M. and Eskandari, M.R. (2019). Chemopreventive effect of quince (Cydonia oblonga Mill.) fruit extract on hepatocellular carcinoma induced by diethylnitrosamine in rats. Int. Pharm. Acta., 2(1):1-12.

Aggarwal, B.B. and Shishodia, S. (2006). Molecular targets of dietary agents for prevention and therapy of cancer. Biochem. Pharmacol., 71:1397-1421

Alam, M.A.; Subhan, N.; Hossain, H.; Hossain, M.; Reza, H.M.; Rahman, M.M. and Ullah, M.O. (2016). Hydroxycinnamic acid derivatives: A potential class of natural compounds for the management of lipid metabolism and obesity. Nutr. Metab., 13:1-13.

Alesiani, D.; Canini, A.; D’Abrosca, B.; DellaGreca, M.; Fiorentino, A.; Mastellone, C.; Monaco, P. and Pacifico, S. (2010). Antioxidant and antiproliferative activities of phytochemicals from quince (Cydonia vulgaris) peels. Food Chem., 118:199-207.

Alizadeh, H.; Rahnema, M.; Semnani, S.N. and Ajalli, M. (2014). Synergistic antifungal effects of quince leaf's extracts and silver nanoparticles on Aspergillus niger. J. Appl. Biol. Sci., 8:10-13.

Alizadeh, H.; Rahnema, M.; Semnani, S.N. and Hajizadeh N. (2013). Detection of compounds and antibacterial effect of quince (Cydonia oblonga Miller) extracts in vitro and in vivo. J. Biol. Act. Prod. Nat., 3:303309.

Alonso-Castro, A.J.; Domínguez, F. and García-Carrancá, A. (2013). Rutin exerts antitumor effects on nude mice bearing SW480 tumor. Arch. Med. Res., 44(5):346-351.

Alsanad, S.M.; Howard, R.L. and Williamson, E.M. (2016). An assessment of the impact of herb-drug combinations used by cancer patients. BMC Complement. Altern. Med., 16:01-09.

Antoniewska, A.; Rutkowska, J. and Pineda, M.M. (2019). Antioxidative, sensory and volatile profiles of cookies enriched with freeze-dried Japanese quince (Chaenomeles japonica) fruits. Food Chem., 286:376-387.

Araújo J.R.; Gonçalves, P. and Martel, F. (2011). Chemo preventive effect of dietary polyphenols in colorectal cancer cell lines. Nutr. Res., 31(2):77-87. 
Ashraf, MU., Muhammad, G; Hussain, M.A. and Bukhari, S.N.A. (2016). Cydonia oblonga M.: A medicinal plant rich in phytonutrients for pharmaceuticals. Front. Pharmacol., 7:163.

Ashrafi, H.; Ghabili, K.; Alihemmati, A.; Jouyban, A.; Shoja, M.M.; Aslanabadi, S.; Adl, F.H.; Ghavimi, H. and Hajhosseini, L. (2012). The effect of quince leaf (Cydonia oblonga Miller) decoction on testes in hypercholesterolemic rabbits: A pilot study. Afr. J. Tradit. Complement. Altern. Med., 10(2):277-282.

Awodele, O.; Oreagba, I.; Popoola, T.D. and Coulidiaty, G. (2018). Herbal medicine use: Remedies or risks 2018. West Afr. Pharm., 29(2):01-18.

Baroni, M. V.; Gastaminza, J.; Podio, N.S.; Lingua, M.S.; Wunderlin, D.A., Rovasio J.L.; Dotti, R.; Rosso, J.C.; Ghione, S. and Ribotta, P.D. (2018). Changes in the antioxidant properties of quince fruit (Cydonia oblonga Miller) during jam production at industrial scale. J. Food Qual., 2018:1-9.

Benzarti, S.; Hamdi, H.; Lahmayer, I.; Toumi, W; Kerkeni, A.; Belkadhi, K. and Sebei, H. (2015). Total phenolic compounds and antioxidant potential of quince (Cydonia oblonga Miller) leaf methanol extract. Int. J Innovation Appl. Stud., 13(5):518-526.

Bevara, GB.; Kumar, N.; Koteshwaramma K.L.; Badana,A.; Kumari,S. and Malla, P.R. (2018). C-glycosyl flavone from Urginea indica inhibits proliferation and angiogenesis and induces apoptosis via cyclindependent kinase 6 in human breast, hepatic and colon cancer cell lines. Indian. J. Med. Res., 147(2):158-168.

Burda, S. and Oleszek, W. (2001). Antioxidant and antiradical activity of flavonoids. J. Agric. Food Chem., 49:2774-2779.

Chen, H.; Miao, Q.; Geng, M.; Liu, J.; Hu, Y.; Tian, L.; Pan, J. and Yang, Y. (2013) Antitumor effect of rutin on human neuroblastoma cell lines through inducing G2/M cell cycle arrest and promoting apoptosis. Scientific World Journal, 2013:269165.

Costa, R.M.; Magalhães, A.S.; Pereira, J.A.; Andrade, P.B.; Valentão, P.; Carvalho, M. and Silva, B.M. (2009). Evaluation of free radical-scavenging and antihemolytic activities of quince (Cydonia oblonga) leaf: A comparative study with green tea (Camellia sinensis). Food Chem. Toxicol., 47(4):860-865.

Daneshvand, B.; Ara, K.M. and Raofie, F. (2012). Comparison of supercritical fluid extraction and ultrasound-assisted extraction of fatty acids from quince (Cydonia oblonga Miller) seed using response surface methodology and central composite design. J. Chromatogr. A., 1252:01-07.

Deep, A.; Marwaha, R.K.; Marwaha, M.G.; Jyoti.; Nandal, R. and Sharma, A.K (2018). Flavopiridol as cyclin dependent kinase (CDK) inhibitor: a review. New J. Chem., 42:18500-18507.

Dinicola, S.; Cucina, A.; Pasqualato, A.; D’Anselmi, F.; Proietti, S.; Lisi, E.; Pasqua G; Antonacci, D. and Bizzarri, M. (2012). Antiproliferative and apoptotic effects triggered by grape seed extract (GSE) versus epigallocatechin and procyanidins on colon cancer cell lines. Int. J. Mol. Sci., 13(1):651-664

Dzhan, T. (2016). The study of fatty and organic acids composition in quince leaves and fruits (Cydonia oblonga mill). EUREKA Life Sci., 5:39-44.

Echard, A.; Droux, J. and Ouest, M. (2014). Cydonia oblonga (quince) leaf extract a new solution for sensitive skin. Ski. Care, 9:10-12.

Erdoðan, T.; Gönenc, T.; Hortooðlu, Z.S.; Demirci, B.; Baser K.H.C. and Kivçak, B. (2012). Chemical composition of the essential oil of Quince (Cydonia oblonga Miller) leaves. Med. Aromat. Plants, 1:01-03.

Fazeenah, A.H.A. and Quamri, M.A. (2016). Behidana (Cydonia oblonga Miller.)- A Review. World. J. Pharm. Res., 5(11):79-94.
Fekri, N.; Khayami, M.; Heidari, R. and Jamee, R. (2008). Chemical analysis of flaxseed, sweet basil, dragon head and quince seed mucilages. Res. J. Biol. Sci., 3(2):166-170.

Ferreres, F.; Silva, B.; Andrade, P.; Seabra, R. and Ferreira, M. (2003). Approach to the study of C-glycosyl flavones by ion trap HPLC-PAD-ESI/ MS/MS: Application to seeds of quince (Cydonia oblonga). Phytochem. Anal., 14:352-359.

Ghafourian, M.; Tamri, P. and Hemmati, A.A. (2015). Enhancement of human skin fibroblasts proliferation as a result of treating with quince seed mucilage. Jundishapur J. Nat. Pharm. Prod., 10:e18820.

Gholami, S.; Hosseini, M.J.; Jafari, L.; Omidvar, F.; Kamalinejad, M.; Mashayekhi, V.; Hosseini, S.H.; Kardan, A.; Pourahmad, J. and Eskandari, M.R. (2017). Mitochondria as a target for the cardioprotective effects of Cydonia oblonga Mill. and Ficus carica L. in doxorubicin-induced cardiotoxicity. Drug Res. (Stuttg)., 67(6):358-365.

Ghopur, H.; Usmanova, S.; Ayupbek, A. and Aisa, H. A. (2012). A new chromone from seeds of Cydonia oblonga. Chem. Nat. Compd., 48(4):562564 .

Gonçalves, C.F.; Santos, M.C.; Ginabreda, M.G; Fortunato, R.S.; Carvalho, D.P. and Freitas Ferreira, A.C. (2013). Flavonoid rutin increases thyroid iodide uptake in rats. PLoS One, 8(9):e73908.

Gründemann, C.;Papagiannopoulos, M.; Lamy, E.;Mersch-Sundermann, V. and Huber R. (2011). Immunomodulatory properties of a lemon-quince preparation (Gencydoß) as an indicator of anti-allergic potency. Phytomedicine: International Journal of Phytotherapy and Phytopharmacology, 18(8-9):760-768.

Hamauzu, Y.; Irie, M.; Kondo, M. and Fujita T. (2008). Antiulcerative properties of crude polyphenols and juice of apple, and Chinese quince extracts. Food Chem., 108:488-495.

Hegedûs, A.; Papp, N. and Stefanovits-Bányai, É. (2013). Review of nutritional value and putative health-effects of quince (Cydonia oblonga Mill.) fruit. Int. J. Hortic. Sci., 19 (3-4):29-32.

Hemmati, A.A.; Kalantari, H.; Rezai, S. and Zadeh, H. (2012). Healing effect of quince seed mucilage on T-2 toxin-induced dermal toxicity in rabbit. Exp. Toxicol. Pathol., 64:181-186.

Hopur, H.; Asrorov, A.; Qingling, M.; Yili, A.; Ayupbek, A.; Nannan, P. and Aisa, H.A. (2011). HPLC analysis of polysaccharides in quince (Cydonia oblonga Mill. var. maliformis) fruit and PTP1B inhibitory activity. Nat. Prod. J., 1(2):146-150

Hou, N.; Liu, N.; Han, J.; Yan, Y. and Li, J. (2016). Chlorogenic acid induces reactive oxygen species generation and inhibits the viability of human colon cancer cells. Anticancer Drugs, 28(1):59-65.

Huang, W.; He, J.; Nisar, M.F.; Li, H. and Wan. C. (2018). Phytochemical and pharmacological properties of Chaenomeles speciosa: An edible medicinal chinese mugua. Evid. Based Complement. Altern. Med., 2018:9591845.

Ishihara, M.; Tsuneya, T.; Shiota, H.; Shiga, M. and Nakatsu, K. (1986). Identification of new constituents of quince fruit flavor (Cydonia oblonga Mill. = C. vulgaris Pers.). J. Org. Chem., 51:491-495.

John, S.; Sivakumar, K.C. and Mishra, R. (2017). Bacoside A induces tumor cell death in human glioblastoma cell lines through catastrophic Macropinocytosis. Front. Mol. Neurosci., 10:171.

Jouki, M.; Tabatabaee, F.; Mortazavi, S. and Koocheki, A. (2014). Quince seed mucilage films incorporated with oregano essential oil: Physical, thermal, barrier, antioxidant and antibacterial properties. Food Hydrocoll., 36:09-19.

Karar, M.G.E.; Pletzer, D.; Jaiswal, R.; Weingart, H. and Kuhnert, N. (2014). Identification, characterization, isolation and activity against Escherichia coli of quince (Cydonia oblonga) fruit polyphenols. Food Res. Int., 65:121-129. 
Karimi, A.; Movahhed, M.; Haji Mehdipoor, H. and Allahyari, F.(2017). A review on Cydonia oblonga Miller as an herbal medicine. INDO Am. J. Pharm. Sci., 4:4370-86.

Khan, R.A.; Khan, M.R. and Sahreen, S. (2012). $\mathrm{CCl}_{4}$-induced hepatotoxicity: Protective effect of rutin on p53, CYP2E1 and the antioxidative status in rat. BMC Complement. Altern. Med., 12:178.

Kim, B.W.; Lee, E.R.; Min, H.M.; Jeong, H.S.; Ahn, J.Y.; Kim, J.H.; Choi, H.Y.; Choi, H.; Kim, E.Y.; Park, S.P. and Cho, S.G. (2008). Sustained ERK activation is involved in the kaempferol-induced apoptosis of breast cancer cells and is more evident under 3-D culture condition. Cancer Biol. Ther., 7(7):1080-1089.

Ku, S.K. and Bae, J.S. (2016). Vicenin-2 and scolymoside inhibit high glucoseinduced vascular inflammation in vitro and in vivo. Can. J. Physiol. Pharmacol., 94(3):287-295.

Kurata, R.; Adachi, M.; Yamakawa, O. and Yoshimoto, M. (2007). Growth suppression of human cancer cells by polyphenolics from sweetpotato (Ipomoea batatas L.) leaves. J. Agric. Food Chem., 55:185-190.

Labbé, D.; Provençal, M.; Lamy, S.; Boivin, D.; Gingras, D. and Béliveau R. (2009). The flavonols quercetin, kaempferol, and myricetin inhibit hepatocyte growth factor-induced medulloblastoma cell migration. J. Nutr., 139:646-652.

Lee, J. and Kim, J.H. (2016). Kaempferol inhibits pancreatic cancer cell growth and migration through the blockade of EGFR-related pathway in vitro. PLoS One, 11(5):e0155264.

Lele, V.; Monstaviciute, E.; Varinauskaite, I.; Peckaityte, G.; Paskeviciute, L.; Plytnikaite, M.; Tamosiunaite, V.; Pikunaite, M.; Ruzauskas, M.; Stankevicius, R. and Bartkiene, E. (2018). Sea buckthorn (Hippophae rhamnoides L.) and quince (Cydonia oblonga L.) juices and their by-products as ingredients showing antimicrobial and antioxidant properties for chewing candy: Nutraceutical formulations. J. Food Qual., 2018:3474202.

Lindberg, B.; Mosihuzzaman, M.; Nahar, N.; Abeysekera, R.M.; Brown, R.G. and Willison, J.H.M. (1990). An unusual (4-O-methyl-d-glucurono)-d-xylan isolated from the mucilage of seeds of the quince tree (Cydonia oblonga). Carbohydr. Res., 207:307-310.

Liu, Y.J.; Zhou, C.Y.; Qiu, C.H.; Lu, X.M. and Wang, Y.T. (2013). Chlorogenic acid induced apoptosis and inhibition of proliferation in human acute promyelocytic leukemia HL-60 cells. Mol. Med. Rep., 8:11061110

Luo, H.; Daddysman, M.K.; Rankin, G.; Jiang B.H. and Chen, Y. (2010). Kaempferol enhances cisplatin's effect on ovarian cancer cells through promoting apoptosis caused by down regulation of cMyc. Cancer Cell Int., 10:16.

Magalhães, A.; Silva, B.; Pereira, J.; Andrade, P.; Valentão, P. and Carvalho, M. (2009). Protective effect of quince (Cydonia oblonga Miller) fruit against oxidative hemolysis of human erythrocytes. Food Chem. Toxicol., 47:1372-1377.

Márcia, C.; Silva, B.M.; Renata, S.; Patrícia, V. and Andrade, P.B. (2010). First report on Cydonia oblonga Miller anticancer potential: Differential antiproliferative effect against human kidney and colon cancer cells. J. Agric. Food Chem., 58:3366-3370.

Marfe, G.; Tafani, M.; Indelicato, M.; Sinibaldi, P.; Reali, V.; Pucci, B, Fini, M. and Russo, M.A. (2009). Kaempferol induces apoptosis in two differen cell lines via Akt inactivation, Bax and SIRT3 activation, and mitochondrial dysfunction. J. Cell. Biochem., 106(4):643-650.

Mathur, P.; Sathishkumar, K.; Chaturvedi, M.; Das, P.; Sudarshan, K.L.; Santhappan, S.; Nallasamy, V.: John, A.; Narasimhan, S. and Roselind, F.S. (2020). Cancer Statistics, 2020: Report from National Cancer Registry Programme, India. JCO Glob. Oncol., 6:1063-75.
Minaiyan, M.; Ghannadi, A.; Etemad, M. and Mahzouni, P. (2012). A study of the effects of Cydonia oblonga Miller (Quince) on TNBS-induced ulcerative colitis in rats. Res. Pharm. Sci., 7:103-110.

Mirmohammadlu, M.; Hosseini, S.H.; Kamalinejad, M.; Gavgani, M.E.; Noubarani, M. and Eskandari, M.R. (2015). Hypolipidemic, hepatoprotective and renoprotective effects of Cydonia oblonga Mill. fruit in streptozotocin-induced diabetic rats. Iran J. Pharm. Res., 14:12071214.

Moosavi,Z;; Meshki, M.; Hemmati,A.A.; Veisi M. and Rafiee, R. (2006). Evaluation of the efficacy of quince mucilage on wound healing. J. Derm. Dis., 9:260-263.

Mousavi, K.; Etebari, M.; Zolfaghari, B. and Jafarian, A. (2015). Evaluation of genoprotective effects of hydroalcoholic and polyphenolic extracts of Quince by comet assay. J. Reports Pharm. Sci., 4:141-147.

Murad, L.D; Soares, Nda. C.; Brand, C.; Monteiro, M.C. and Teodoro, A.J. (2015). Effects of caffeic and 5-caffeoylquinic acids on cell viability and cellular uptake in human colon adenocarcinoma cells. Nutr. Cancer., 67(3):532-542.

Murayama, T.; Yada, H., Kobori, M., Shinmoto, H. and Tsushida, T. (2002). Evaluation of three antioxidants and their identification and radical scavenging activities in edible Chrysanthemums. Engei Gakkai Zasshi., 71:236-242.

Nagaprashantha, L.D.; Vatsyayan, R.; Singhal, J.; Fast, S.; Roby, R.; Awasthi, S. and Singhal, S.S. (2011). Anticancer effects of novel flavonoid vicenin-2 as a single agent and in synergistic combination with docetaxel in prostate cancer. Biochem. Pharmacol., 82:1100-1109.

Nijveldt, R.J.; van Nood, E.; van Hoorn, D.E.; Boelens, P.G.; van Norren, K. and van Leeuwen, P.A. (2001). Flavonoids: A review of probable mechanisms of action and potential applications. Am. J. Clin. Nutr., 74(4):418425 .

Oliveira, A.P.; Pereira, J.A.; Andrade, P.; Valentão, P.; Seabra, R.M. and Silva, B.M. (2007). Phenolic profile of Cydonia oblonga miller leaves. J. Agric. Food. Chem., 55:7926-7930.

Oliveira, A.P.; Pereira, J.A.; Andrade, P.B.; Valentão, P.; Seabra, R.M. and Silva, B.M. (2008). Organic acids composition of Cydonia oblonga Miller leaf. Food Chem., 111:393-399.

Osman, A.G.; Koutb, M. and Sayed Ael-D. (2010). Use of hematological parameters to assess the efficiency of quince (Cydonia oblonga Miller) leaf extract in alleviation of the effect of ultraviolet: A radiation on African catfish Clarias gariepinus (Burchell, 1822). J. Photochem. Photobiol. B. Biol., 99(1):01-08.

Pacifico, S.; Gallicchio, M.; Fiorentino, A.; Fischer, A. and Stintzing, F. (2012) Antioxidant properties and cytotoxic effects on human cancer cell lines of aqueous fermented and lipophilic quince (Cydonia oblonga Mill.) preparations. Food Chem. Toxicol., 50:4130-4135.

Phromnoi, K.; Yodkeeree, S.; Anuchapreeda, S. and Limtrakul P. (2009). Inhibition of MMP-3 activity and invasion of the MDA-MB-231 human invasive breast carcinoma cell line by bio flavonoids. Acta Pharmacol. Sin., 30(8): 1169-1176.

Postman, J. (2009). Cydonia oblonga: The unappreciated quince. Arnoldia, 67:2-9.

Rahimi, R.; Shams-Ardekani, M.R. and Abdollahi, M. (2010). A review of the efficacy of traditional Iranian medicine for inflammatory bowel disease. World J. Gastroenterol., 16:4504-4514.

Ramos, S. (2008). Cancer chemoprevention and chemotherapy: Dietary polyphenols and signaling pathways. Mol. Nutr. Food Res., 52(5):507-526. 
Riahi-Chebbi, I.; Haoues, M.; Essafi, M.; Zakraoui, O.; Fattouch, S.; Karoui, H. and Essafi-Benkhadir, K. (2016). Quince peel polyphenolic extract blocks human colon adenocarcinoma LS174 cell growth and potentiates 5fluorouracil efficacy. Cancer Cell Int., 16:1.

Robinson, M. and Zhang, X. (2011). The World Medicines Situation 2011 Traditional Medicines: Global Situation, Issues and Challenges., 3rd Edition., pp:01-14.

Rubinskienë, M.; Viðkelis, P.; Viðkelis, J.; Bobinaitë, R..; Shalkevich, M. Pigul, M. and Urbonavièienë, D. (2014). Biochemical composition and antioxidant activity of Japanese quince (Chaenomeles japonica) fruit, their syrup and candied fruit slices. SodininkystëirDarpininkystë, 33:4552.

Sabale, P.; Bhimani, B.; Prajapati, C. and Sabalea, V. (2012). An overview of medicinal plants as wound healers. J. Appl. Pharm. Sci., 2:143-150.

Sayed, A.H.; Abdel-Tawab, H.S.; Abdel Hakeem, S.S. and Mekkawy, I.A. (2013). The protective role of quince leaf extract against the adverse impacts of ultraviolet: A radiation on some tissues of Clarias gariepinus (Burchell, 1822). J. Photochem. Photobiol. B. Biol. 119:09-14.

Schwingel, T.E; Klein, C.P; Nicoletti, N.F; Dora, C.L; Hadrich, G; Bica, C.G; Lopes, T.G.; da Silva, V.D and Morrone, F.B. (2014). Effects of the compound's resveratrol, rutin, quercetin, and quercetin nanoemulsion on oxaliplatin-induced hepatotoxicity and neurotoxicity in mice. NaunynSchmiedebergs Arch. Pharmacol., 387(9): 837-848.

Seabra, R.M.; Andrade, P.; Valentão, P.; Fernandes, E.; Remião, F. and Bastos, M.L (2006). Antioxidant compounds extracted from several plant materials. Biomaterials from Aquatic and Terrestial Organisms, CRC Press, pp:115-174

Shinomiya, F.; Hamauzu, Y. and Kawahara T. (2009). Antiallergic effect of a hot-water extract of quince (Cydonia oblonga). Biosci. Biotechnol. Biochem., 73:1773-1778.

Siegel, R.L.; Miller, K.D. and Jemal A. (2020). Cancer Statistics, 2020. C.A. Cancer. J. Clin., 70:07-30.

Silva, B.; Andrade, P.; Gonçalves, A.; Seabra, R.; Oliveira, M. and Ferreira, M. (2004a). Influence of jam processing upon the contents of phenolics, organic acids and free amino acids in quince fruit (Cydonia oblonga Miller). Eur. Food Res. Technol., 218:385-389.

Silva, B.M.; Andrade, P.; Ferreres, F.; Seabra, R.M.; Oliveira, M.B.P.P. and Ferreira, M.A. (2005). Composition of quince (Cydonia oblonga Miller) seeds: Phenolics, organic acids and free amino acids. Nat. Prod. Res., 19:275-281

Silva, B.M.; Andrade,P.B.; Ferreres, F.; Domingues, A.L.; Seabra, R.M. and Ferreira, M.A. (2002a). Phenolic profile of quince fruit (Cydonia oblonga Miller) (pulp and peel). J. Agric. Food Chem., 50:4615-4618.

Silva, B.M.; Andrade, P.B.; Mendes, G.C.; Seabra, R.M. and Ferreira, M.A. (2002b). Study of the organic acid composition of quince (Cydonia oblonga Miller) fruit and jam. J. Agric. Food Chem., 50:2313-2317.

Silva, B.M.; Andrade, P.B.; Valentão, P.; Ferreres, F.; Seabra, R.M. and Ferreira, M.A (2004). Quince (Cydonia oblonga Miller) fruit (pulp, peel and seed) and jam: Antioxidant activity. J. Agric. Food. Chem., 52:47054712 .

Singhal, S.S.; Jain, D.; Singhal, P.; Awasthi, S.; Singhal, J. and Horne D. (2017). Targeting the mercapturic acid pathway and vicenin-2 for prevention of prostate cancer. Biochim. Biophys. Acta., 1868(1):167-175.

Srivastava, K.K.; Jabeen, A.; Das, B. and Sharma, A.K. (2005). Genetic variability of quince (Cydonia oblonga) in Kashmir valley. Indian. J. Agric. Sci., 75:766-768
Stortelers, C.; Kerkhoven, R. and Moolenaar, W. (2008). Multiple actions of LPA on fibroblasts revealed by transcriptional profiling. BMC Genomics., 9:387.

Sudan, S. and Rupasinghe, H.P. (2014). Quercetin-3-O-glucoside induces human DNA topoisomerase II inhibition, cell cycle arrest and apoptosis in hepatocellular carcinoma cells. Anticancer Res., 34(4):1691-1699.

Sun, D.; Cao, M.; Li, H.; He, S. and Chen, W. (2020). Cancer burden and trends in China: A review and comparison with Japan and South Korea. Chin J. Cancer Res., 32:129-39.

Sut, S.; Dall'Acqua, S.; Poloniato, G.; Maggi, F. and Malagoli, M. (2019). Preliminary evaluation of quince (Cydonia oblonga Mill.) fruit as extraction source of antioxidant phytoconstituents for nutraceutical and functional food applications. J. Sci. Food Agric., 99:1046-1054.

Szychowski, P.J.; Munera-Picazo, S.; Szumny, A.; Carbonell-Barrachina, Á.A. and Hernández, F. (2014). Quality parameters, biocompounds, antioxidant activity and sensory attributes of Spanish quinces (Cydonia oblonga Miller). Sci. Hortic. (Amsterdam)., 165:163-170.

Tajoddini, A.; Rafieian-kopaei, M.; Namjoo, A.R.; Sedeh, M.; Ansari, R. and Shahinfard, N. (2013). Effect of Ethanolic Extract of Cydonia oblonga seed on the healing of Second-Degree Burn Wounds. Armaghan-eDanesh, 17(6):494-501.

Tamri, P.; Hemmati, A. and Boroujerdnia, M.G. (2014). Wound healing properties of quince seed mucilage: In vivo evaluation in rabbit full-thickness wound model. Int. J. Surg., 12:843-847.

Tateo, F. and Bononi, M. (2010). Headspace-SPME analysis of volatiles from quince whole fruits. J. Essent. Oil. Res., 22:416-418.

Tita, I.; Mogosanu, G. and Tita, M. (2009). Ethnobotanical inventory of medicinal plants from the South-West of Romania. Farmacia, 57:141-156.

Tsuneya, T.; Ishihara, M.; Shiota, H. and Shiga, M. (1983). Volatile components of quince fruit (Cydonia oblonga Mill.). Agric. Biol. Chem., 47:2495-2502.

Ulrich, C.; Bigler, J. and Potter, J. (2006). Non-steroidal anti-inflammatory drugs for cancer prevention: Promise, perils and pharmacogenetics. Nat. Rev. Cancer., 6:130-140.

Vaez, H.; Hamidi, S. and Arami, S. (2014). Potential of Cydonia oblonga leaves in cardiovascular disease. Hypothesis, 12:1-10.

Velièkoviæ,D.T.; Ristiæ, M.S.; Milosavljeviæ, N.P.; Davidoviæ, D.N.; Milenoviæ, D.M. and Velièkoviæ, A.S. (2016). Volatiles of quince fruit and leaf (Cydonia oblonga Mill.) from Serbia. BiologicaNyssana, 7(2):145-149.

Vitaglione, P.; Fogliano, V. and Pellegrini, N. (2012). Coffee, colon function and colorectal cancer. Food Funct., 3:916-922.

Vuong, Q.V.; Hirun, S.; Phillips, P.A.; Chuen, T.L.; Bowyer, M.C.; Goldsmith, C.D. and Scarlett, C.J. (2014). Fruit-derived phenolic compounds and pancreatic cancer: Perspectives from Australian native fruits. J. Ethnopharmacol., 152(2):227-242.

Wang, J.; Fang, X.; Ge, L.; Cao, F.; Zhao, L.; Wang, Z and Xiao, W. (2018). Antitumor, antioxidant and anti-inflammatory activities of kaempferol and its corresponding glycosides and the enzymatic preparation of kaempferol. PLoS One, 13(5): e0197563.

Wang, Y.; Tang, C. and Zhang, H. (2015). Hepatoprotective effects of kaempferol 3-O-rutinoside and kaempferol 3-O-glucoside from Carthamus tinctorius L. on CCl4-induced oxidative liver injury in mice. J. Food Drug Anal., 23:310-317. 
Williamson, E.M.; Liu, X. and Izzo, A.A. (2020). Trends in use, pharmacology, and clinical applications of emerging herbal nutraceuticals. Br. J. Pharmacol., 177:1227-1240.

Winterhalter, P. and Schreier, P. (1988). Free and bound C13 norisoprenoids in quince (Cydonia oblonga, Mill.) fruit. J. Agric. Food Chem., 36:12511256.

Wojdy $^{3}$ o, A.; Oszmiañski, J. and Bielicki, P. (2013). Polyphenolic composition, antioxidant activity, and polyphenol oxidase (PPO) activity of quince (Cydonia oblonga Miller) varieties. J. Agric. Food Chem., 61:2762-2772.

Xavier, R.J. and Podolsky, D.K. (2007). Unravelling the pathogenesis of inflammatory bowel disease. Nature, 448:427-434.

Yagasaki, K.; Miura, Y.; Okauchi, R. and Furuse, T. (2000). Inhibitory effects of chlorogenic acid and its related compounds on the invasion of hepatoma cells in culture. Cytotechnology, 33:229-235.

Yamagata, K.; Izawa, Y.; Onodera, D. and Tagami, M. (2018). Chlorogenic acid regulates apoptosis and stem cell marker-related gene expression in A549 human lung cancer cells. Mol. Cell. Biochem., 441:09-19.

Yang, D.; Zhang, X.; Zhang, W. and Rengarajan T. (2018). Vicenin-2 inhibits Wnt/â-catenin signaling and induces apoptosis in HT-29 human colon cancer cell line. Drug Des. Devel. Ther., 12:1303-1310.
Yang, J. and Liu, R.H. (2009). Synergistic effect of apple extracts and quercetin 3-beta-D-glucoside combination on antiproliferative activity in MCF-7 human breast cancer cells in vitro. J. Agric. Food Chem., 57(18):8581-8586.

Yang, J.S.; Liu, C.W.; Ma, Y.S.; Weng, S.W.; Tang, N.Y.; Wu, S.H.; Ji, B.C., Ko, Y.C.; Funayama, S. and Kuo, C.L. (2012). Chlorogenic acid induces apoptotic cell death in U937 leukemia cells through caspase-and mitochondriadependent pathways. In vivo, 26:971-978.

Yildirim, A.; Oktay, M. and Bilaloglu, V. (2001). The antioxidant activity of the leaves of Cydonia vulgaris. Turk. J. Med. Sci., 31:23-27.

You, H.J; Ahn, H.J. and Ji, G.E. (2010). Transformation of rutin to antiproliferative quercetin-3-glucoside by Aspergillus niger. J. Agric. Food Chem., 58(20):10886-10892.

Zhou, W.; Abdurahman, A.; Umar, A.; Iskander, G.; Abdusalam, E.; Berké, B.; Bégaud, B. and Moore, N. (2014). Effects of Cydonia oblonga Miller extracts on blood hemostasis, coagulation and fibrinolysis in mice, and experimental thrombosis in rats. J. Ethnopharmacol., 154(1):163-169.

Zhou,X.;Seto, S.W.; Chang, D.;Kiat, H.;Razmovski-Naumovski, V.; Chan, K. and Bensoussan, A. (2016). Synergistic effects of Chinese herbal medicine: A comprehensive review of methodology and current research. Front Pharmacol., 7:201.

Elhan Khan and Iffat Zareen Ahmad (2021). An insight into the prophylactic and therapeutic activities of golden apple (Cydonia oblonga Miller), cultivated in Kashmir valley of India, for the future cancer care and prevention: A review. Ann. Phytomed., 10(2):22-35. http://dx.doi.org/10.21276/ap.2021.10.2.3 